Article

\title{
The Impact of Vacuum and Convective Drying Parameters on Kinetics, Total Phenolic Content, Carotenoid Content and Antioxidant Capacity of Kiwiberry (Actinidia arguta)
}

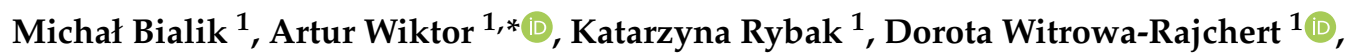 \\ Piotr Latocha ${ }^{2}$ and Ewa Gondek ${ }^{1}$ \\ 1 Department of Food Engineering and Process Management, Institute of Food Sciences, \\ Warsaw University of Life Sciences (WULS-SGGW), Nowoursynowska 159c, 02-776 Warsaw, Poland; \\ michal_bialik@sggw.edu.pl (M.B.); katarzyna_rybak@sggw.edu.pl (K.R.); \\ dorota_witrowa_rajchert@sggw.edu.pl (D.W.-R.); ewa_gondek@sggw.edu.pl (E.G.) \\ 2 Department of Environmental Protection and Dendrology, Institute of Horticulture Sciences, \\ Warsaw University of Life Sciences (WULS-SGGW), Nowoursynowska 159, 02-776 Warsaw, Poland; \\ piotr_latocha@sggw.edu.pl \\ * Correspondence: artur_wiktor@sggw.pl; Tel.: +48-22-593-75-60
}

Received: 27 August 2020; Accepted: 30 September 2020; Published: 2 October 2020

Featured Application: Fresh kiwiberry has strong antioxidant properties but has a short shelf life. Hence, dried fruit has great potential in being widely consumed as a health beneficial fruit.

\begin{abstract}
This study aimed to investigate the impact of convective and vacuum drying performed at different temperatures on the content of bioactive components of kiwiberry. Dried fruits obtained from Geneva and Weiki cultivars were analyzed for total carotenoid content, total phenolic content (TPC), and antioxidant activity using 2,2-diphenyl-1-picrylhydrazyl (DPPH) and 2,2'-azino-bis (3-ethylbenzothiazoline-6-sulfonic acid) (ABTS) assays. The secondary goal was to establish drying kinetics and to find the best-fitting model for the drying process. The results showed that the highest total carotenoid content was found in Geneva fruits dried by vacuum method and was equal to 39.55-90.27 $\mu \mathrm{g} / \mathrm{g}$ dry matter (d.m.). Considering free radical scavenging activity, the best results were also achieved for vacuum dried Geneva cultivar. These samples exhibited EC50 equal to $0.16-0.51 \mathrm{mg}$ d.m./mL and $0.05-0.24 \mathrm{mg}$ d.m./mL as evaluated using DPPH and ABTS assays, respectively. Vacuum drying method usually better preserved the phenolic content of kiwiberry-samples dried at $50{ }^{\circ} \mathrm{C}$ did not differ significantly from fresh material. Generally, the shortest drying time was observed for the samples dried at $70^{\circ} \mathrm{C}$ regardless of the drying method. Changing the temperature during drying from 80 to 50 and $60^{\circ} \mathrm{C}$ did not cause expected benefits regarding chemical property preservation. In most cases, the Midilli et al. model represented the best fit to describe obtained drying kinetics.
\end{abstract}

Keywords: Actinidia arguta; carotenoids; antioxidant capacity; drying kinetics

\section{Introduction}

Kiwiberry (Actinidia arguta) is a plant which can be grown in different parts of the world and originates from eastern China [1]. Kiwiberry fruits are ten-fold smaller than Kiwi (Actinidia chinesis) and have smooth, hairless skin. Clean and thin skin allows fruits to be eaten whole but affects their shelf life. They can be stored up to one week after reaching consumption maturity [2]. Kiwiberry fruits are a good 
source of vitamin C, carotenoids chlorophylls, anthocyanins, and phenolic acids [1,2]. Such composition results in strong antioxidant properties, which was confirmed by displaying protective activity against induced hypercholesterolemia on rats [3].

Convective drying provides relatively inexpensive products [4]. Vacuum or sublimation drying (freeze-drying) offer a higher quality product but at significantly higher costs [5]. Previously reported results indicate that, among different drying methods of kiwiberry such as convective drying, infrared-assisted air drying, microwave-assisted air drying, and the two methods vacuum drying are the most promising and worth further investigation [6]. Therefore, based on these results in this experiment, the convective method was used because of its simplicity and popularity in the industry whereas the vacuum drying was chosen as a method for obtaining products with potentially improved retention of bioactive compounds and better rehydration properties [6].

The most common dietary antioxidants are carotenoids, flavonoids, and vitamins $\mathrm{C}$ and $\mathrm{E}$. During the last decade, researchers analyzed the impact of antioxidants on people's health $[7,8]$. These experiments increased interest in investigating foods that possess strong antioxidant properties. Epidemiological studies suggest that consumption of such products reduces the risk of chronic diseases such as previously mentioned cardiovascular diseases and cancer [9].

This work aimed (i) to analyze the impact of drying methods performed at different temperatures on selected chemical parameters of dried kiwiberry fruits and (ii) to characterize drying kinetics using a mathematical modeling approach. Within the secondary aim of the study, obtained by means of mathematical modelling, the effective water diffusion coefficient that describes water removal efficiency was compared with analyzed properties of dried kiwiberry.

\section{Materials and Methods}

\subsection{Plant Material}

The study was carried out using two commodity cultivars of kiwiberry (Actinidia arguta): Geneva and Weiki. Plants grew in the commercial orchard under the supervision of scientists from the Department of Environment Protection at Warsaw University of Life Sciences (WULS-SGGW), Poland. Fruits were collected at the eating maturity stage (soft) and were stored in darkness in a cold room at $4{ }^{\circ} \mathrm{C}$ maximally for one week before processing. Before each experiment, fruits were removed from the storage compartment, and after reaching room temperature $\left(22^{\circ} \mathrm{C}\right)$, they were washed with tap water and cut into halves. Before being placed in the dryer, fruits were put on filter paper in order to remove excess water and were then cut into halves.

\subsection{Drying}

The drying procedure was performed in custom-made convective (CD) and vacuum (VD) laboratory dryers. The test runs established that high temperature can be used only during the first stage drying kinetics and that the maximum nondestructive temperature is $80^{\circ} \mathrm{C}$. That is why two-stage drying $\left(80-50\right.$ and $80-60^{\circ} \mathrm{C}$ ) was introduced as a method for potentially improving drying kinetics without damaging tissue or thermolabile compounds [10]. The time of the first-stage drying was established as 105 and $150 \mathrm{~min}$ for the CD and VD methods, respectively. The decision about the length of the first-stage was done based on preliminary tests and on analysis of the kinetics of the process. The lowest drying temperature was determined by the acceptable duration of the process (under $36 \mathrm{~h}$ ). As a result, kiwiberry was dried at 50, 60, 70, 80-50, and $80-60^{\circ} \mathrm{C}$. Halves of fruits were placed on perforated single trays with samples facing a cut surface upwards, both in the case of $C D$ and VD. Fruits were arranged in such a way that their surface took the shape of the perforated tray and had a height of about $0.75 \mathrm{~cm}$ and a density of $3.95 \mathrm{~kg} / \mathrm{m}^{2}$. Both dryers were connected to the computer for recording measurements from balances in the set time intervals. For CD drying, external balance was suspended in the drying chamber. Weighing in the vacuum dryer was performed by the specially designed internal weighing system reported previously in the literature [11]. Airflow during 
CD was parallel to the samples, and its velocity was $2 \mathrm{~m} / \mathrm{s}$. Vacuum drying was performed under a pressure of $4 \mathrm{kPa}$. The process was performed until a dimensionless moisture ratio (MR) of 0.02 was achieved (when estimated weight based on the dry substance content in the raw material was achieved). Weight of the material was recorded every 2 min with an accuracy of $0.1 \mathrm{~g}$. Dry matter (d.m.) content in raw and dried fruits was measured according to the AOAC (Association of Official Agricultural Chemists) 920.151 standard [12]. Drying runs were performed in duplicate. After two drying runs, all dried fruits were gathered, packed, and stored before needed. Samples were randomly selected from the package for quality analysis.

\subsection{Dried Fruits Storage}

Dried fruits were stored at room temperature in sealed multilayer barrier packages blocking light and preventing moisture and gas exchange (without modification of air composition). The time of storage before analysis was not longer than one week.

\subsection{Extraction}

Dried fruits were ground using an IKA A11 mill (IKA-Werke GmbH \& Co. KG, Staufen, Germany). Then, $1.2 \pm 0.001 \mathrm{~g}$ of powder was transferred to the beakers and 25 of $80 \% v / v$ aqueous solution of ethanol was added. Samples were homogenized using an IKA T25 homogenizer. The obtained solution was heated to reflux, filtered into 50-mL volumetric flasks, and filled with an ethanol solution. The procedure was repeated twice for each sample.

\subsection{ABTS Assay}

The 2,2-azinobis-(3-ethylbenzothiazoline-6-sulfonic acid) radical (ABTS ${ }^{\bullet+}$ ) solution was prepared by mixing $3.84 \mathrm{mM}$ of ABTS with $0.002 \mathrm{mM}$ of potassium persulfate in water and by incubating in the dark for $>16 \mathrm{~h}$. Then, a stock solution of $\mathrm{ABTS}^{\bullet+}$ was diluted with phosphate buffered saline to a final absorbance of $0.72( \pm 0.2)$ at $734 \mathrm{~nm}$. Finally, $3 \mathrm{~mL}$ of $\mathrm{ABTS}^{\bullet+}$ solution was added to four kiwiberry extracts containing $0.01,0.02,0.03$, and $0.04 \mathrm{~mL}$ (as filled up to $2 \mathrm{~mL}$ of ethanol). The absorbance was measured in two repeats after $10 \mathrm{~min}$ in a Helios v. 7.03 spectrophotometer (Thermo Electron Corporation, Waltham, MA, USA) at a wavelength of $734 \mathrm{~nm}$ against ethanol solution as a blank. Results were expressed as $\mathrm{EC}_{50}$ (ABTS) (concentration of dry matter of extracts needed to scavenge $50 \%$ of initial $\mathrm{ABTS}^{\bullet+}$ ). The measurement was performed in two replicates for each extract.

\subsection{DPPH Assay}

The 2,2-diphenyl-1-picrylhydrazyl (DPPH) radical scavenging activity of kiwiberry extracts was determined as described Brand-Williams et al. [13]. Six extracts at 0.02, 0.07, 0.14, 0.2, 0.26, and $0.32 \mathrm{~mL}$ were filled up to $2 \mathrm{~mL}$ using $80 \% v / v$ aqueous solution of ethanol and then mixed with $2 \mathrm{~mL}$ of $0.22 \mathrm{mM}$ DPPH• solution. The absorbance measurement was carried out using Helios v. 7.03 spectrophotometer after $30 \mathrm{~min}$ of incubation at $23^{\circ} \mathrm{C}$ in darkness at a wavelength of $517 \mathrm{~nm}$ against the ethanol solution (as a blank). Results were expressed as EC50 (DPPH) (concentration of dry matter of extracts needed to scavenge $50 \%$ of initial DPPH•). The test was repeated twice for each extract.

\subsection{Total Carotenoid Content}

The total carotenoid content was measured in two replicates using Polish Standard PN EN 12136:2000 [14] with petroleum ether and acetone as the organic solvents. Before extraction, samples were mixed with Carrez solutions, stirred, and centrifuged to remove proteins from the sample. Afterward, $80 \% v / v$ acetone solution was used to extract carotenoids from dried and powdered kiwiberry. The sediment was centrifuged at $14,000 \mathrm{rpm}(2000 \times \mathrm{g})$ for $7 \mathrm{~min}$ using SIGMA 4-15 centrifuge (Sigma Laborzentrifugen $\mathrm{GmbH}$, Osterode, Germany). Then, ether was added to the supernatant, which allowed the water to be removed from the sample while preserving carotenoids in the 
organic solution. Absorbance of the supernatant was measured at $450 \mathrm{~nm}$ using a Helios v. 7.03 spectrophotometer with ether used as a blank. Total carotenoid content was estimated using the equations provided by Lichtenhaler and Wellburn [15] and expressed on a dried weight basis as $\beta$-carotene equivalent $\mu \mathrm{g} / \mathrm{g}$ d.m.

\subsection{Total Phenolic Content}

Polyphenols were extracted from dried, powdered kiwiberry using $80 \%$ ethanol solution. Two independent extracts were prepared from each variant of the experiment. Obtained extracts were used for total phenolic content (TPC) and free radical scavenging activity determinations (ABTS and DPPH method). The total phenolic content was determined following the procedure by Singleton and Rossi [16] with some modifications. In this experiment, $30 \mathrm{~mL}$ of distilled water, $1.5 \mathrm{~mL}$ of extract, and $3 \mathrm{~mL}$ of Folin-Ciocalteau reagents were mixed, and after 3 min of incubation, $2 \mathrm{~mL}$ of sodium carbonate $18 \%$ was added. Afterward, the samples were filled with distilled water up to $50 \mathrm{~mL}$, mixed, and kept at $23{ }^{\circ} \mathrm{C}$ in darkness for $1 \mathrm{~h}$. The absorbance was measured against a blank sample (without extract) at $750 \mathrm{~nm}$ using Helios v. 7.03 spectrophotometer. The total phenolic content was expressed as $\mathrm{mg}$ of gallic acid equivalent per gram of dry matter (mg GAE/g d.m.).

\subsection{Mathematical Modeling}

Mathematical models, listed in Table 1 [17-24], were used to evaluate the drying kinetics of kiwiberry. Drying curves were plotted as a time function of dimensionless moisture ratio (MR), which was calculated according to Wiktor et al. [25]:

$$
M R=\frac{u_{\tau}}{u_{0}}
$$

where $u_{0}$ is the initial moisture content in $\mathrm{g} \mathrm{H}_{2} \mathrm{O} / \mathrm{g} \mathrm{d}$.m. and where $u_{\tau}$ is the moisture content at each moment of the process in $\mathrm{g} \mathrm{H}_{2} \mathrm{O} / \mathrm{g} \mathrm{d}$.m. $M R$ is an empirical value derived from Fick's second law of diffusion, which states that transfer rate is proportional to the rate of change of concentration in the function of time [26].

Table 1. The mathematical models used in the experiment.

\begin{tabular}{cccc}
\hline Model № & Model Name & Model Equation & Reference \\
\hline 1 & Newton & $M R=\exp (-k \cdot \tau)$ & {$[17]$} \\
2 & Page & $M R=\exp \left(-k \cdot \tau^{a}\right)$ & {$[18]$} \\
3 & Henderson and Pabis & $M R=\mathrm{a} \cdot \exp (-k \cdot \tau)$ & {$[19]$} \\
4 & Logarithmic & $M R=a \cdot \exp (-k \cdot \tau)+b$ & {$[18]$} \\
5 & Midilli et al. & $M R=\mathrm{a} \cdot \exp \left(-k \cdot \tau^{c}\right)+b \cdot \tau$ & {$[20]$} \\
6 & Wang and Singh & $M R=1+\mathrm{a} \cdot \tau+b \cdot \tau^{2}$ & {$[21]$} \\
7 & Logistic & $M R=\frac{b}{(1+\mathrm{a} \cdot \exp (k \cdot \tau))}$ & {$[22]$} \\
8 & Two-factor & $M R=a \cdot \exp (-k \cdot \tau)+b \cdot \exp \left(-k_{i} \cdot \tau\right)$ & {$[23]$} \\
9 & Simplified Fick's second law of diffusion & $M R=\frac{8}{\pi^{2}} \cdot \exp \left(-\frac{\pi^{2} \cdot D_{e f f} \cdot \tau}{4 \cdot L^{2}}\right)$ & {$[24]$} \\
\hline
\end{tabular}

$k, k_{i}$ drying rates (1/min); $a, b$, and $n$, model parameters; $\tau$, time (s); $D_{\text {eff }}$, the effective water diffusion coefficient $\left(\mathrm{m}^{2} / \mathrm{s}\right)$; and $L$, half of the material thickness $(\mathrm{m})$.

Regression analysis was performed using Table Curve 2D v5.01 software (SYSTAT Software Inc., Chicago, Ill., USA). To evaluate model fit, coefficient of determination $\left(R^{2}\right)$, reduced chi-squared statistic $\left(\chi^{2}\right)$, and root mean square error (RMSE) were used and calculated as follows:

$$
R^{2}=1-\frac{\sum_{i=1}^{N}\left(M R_{i, p}-M R_{i, e}\right)^{2}}{\sum_{i=1}^{N}\left(M R_{i, e}-M R_{p}\right)^{2}}
$$




$$
\begin{aligned}
\text { RMSE } & =\sqrt{\frac{\sum_{i=1}^{N}\left(M R_{i, p}-M R_{i, e}\right)^{2}}{N}} \\
\chi^{2} & =\frac{\sum_{i=1}^{N}\left(M R_{i, p}-M R_{i, e}\right)^{2}}{N-n}
\end{aligned}
$$

where $M R_{i, p}$ is the predicted dimensionless moisture ratio, $M R_{i, e}$ is the experimental dimensionless moisture ratio, $M R_{\mathrm{p}}$ is the mean experimental moisture ratio, $N$ is the number of the observations, and $n$ is the number of the constants in the model equation. $\mathrm{R}^{2}$ values approximating to 1 and low $\chi^{2}$ and RMSE values indicate that the model offers a better fit for the experimental data. Moreover, the effective water diffusion coefficient was computed using Table Curve 2D v5.01 software from the simplified equation for Fick's second law of diffusion (Table 1) for an infinite slab since the fruits were arranged in the shape of slabs and were placed next to one another on a perforated tray, which allowed evaporation to take place from both sides. An approximation of this type is acceptable assuming no shrinkage of the material [27].

\subsection{Statistical Analysis}

The statistical significance of all measured parameters was tested using one-way and multifactorial analysis of variance (ANOVA) with a significance level of $\alpha=0.05$. In the case of significant associations, post hoc Tukey's and Duncan's tests were performed. Moreover, Pearson's correlation analysis was performed in order to evaluate the correlation between the selected parameters. Analysis of the experimental data was carried out using Statistica 12 (Dell, Round Rock, Tex., USA) and Excel 2015 (Microsoft, Redmond, WA, USA).

\section{Results}

\subsection{Biochemical Properties}

In the current study, among all dried samples, the highest $\mathrm{EC}_{50}$ (ABTS) values were obtained for CD dried Weiki cultivars and ranged from 0.25 to $0.83 \mathrm{mg} \mathrm{d.m./mL} \mathrm{(Table} \mathrm{2).} \mathrm{Using} \mathrm{DPPH} \mathrm{assay,}$ the lowest antioxidant activity amid Weiki samples was determined for kiwiberry dried (CD) at 50 and $70{ }^{\circ} \mathrm{C}$; these values were significantly different $(p<0.05)$ from all other dried samples. In turn, amid Geneva samples, the lowest antioxidant activity was characteristic for samples dried also by the convective method although at temperatures above $60^{\circ} \mathrm{C}$. The lowest values of $\mathrm{EC}_{50}(\mathrm{DPPH})$, which point at strong antioxidant properties, were measured for VD Geneva at $50{ }^{\circ} \mathrm{C}$. In this case, antioxidant capacity was equal to $0.16 \mathrm{mg} \mathrm{d} . \mathrm{m} . / \mathrm{mL}$. In all tested conditions, there were no statistical differences between ABTS and DPPH values from fresh and VD samples dried at $50{ }^{\circ} \mathrm{C}$.

Total carotenoid content (TCC) of dried fruits ranged between 36.55-90.27 and 35.08-61.88 $\mu \mathrm{g} / \mathrm{g}$ d.m. for Geneva and Weiki, respectively. Among Geneva fruits, the highest concentration of carotenoids not significantly different from the fresh samples was obtained for the VD method performed at $60^{\circ} \mathrm{C}$. In the case of Weiki samples, the highest values were stated for VD performed at $50{ }^{\circ} \mathrm{C}$ and $80-50{ }^{\circ} \mathrm{C}$; in these cases, carotenoid content was equal to 61.49 and $61.88 \mu \mathrm{g} / \mathrm{g} \mathrm{d}$.m., respectively. The lowest concentration of carotenoids, equal to $35.08 \mu \mathrm{g} / \mathrm{g} \mathrm{d}$.m., was found in Weiki dried convection method at $50^{\circ} \mathrm{C}$. Such results are linked to the long exposure to oxygen and to oxidation of carotenoids resulting from the longest drying time. Pearson's correlation analysis proved that the relationship between drying time and total carotenoid content was negative and statistically significant $(r=-0.475)$.

The highest statistically different TPC value in comparison to other dried samples was stated for extracts of Geneva cultivar vacuum dried at $50{ }^{\circ} \mathrm{C}: 44.89 \mathrm{mg} \mathrm{GAE} / \mathrm{g}$ d.m. It is worth emphasizing that this sample did not differ significantly from fresh fruits. In comparison, the lowest values were measured for CD dried Weiki, which were characterized by TPC equal to 4.77 and $4.83 \mathrm{mg}$ GAE/g d.m. for drying at 50 and $60^{\circ} \mathrm{C}$, respectively. The TPC values correlated significantly with both antioxidant activity determinants analyzed by ABTS and DPPH assays. The values of coefficients of correlation 
were equal to $\mathrm{r}=-0.673$ and $\mathrm{r}=-0.640$, respectively. Average correlation was discovered between $\mathrm{EC}_{50}$ parameters and total carotenoid content, $r=-0.330$ for ABTS and $r=-0.402$ for DPPH, which indicates that free radical scavenging activity resulted mainly from phenolics presence.

Table 2. Biochemical properties of dried kiwiberry samples.

\begin{tabular}{|c|c|c|c|c|c|}
\hline Cultivar & $\begin{array}{l}\text { Method and } \\
\text { Temperature }\end{array}$ & $\begin{array}{l}\text { EC } 50 \text { ABTS } \\
\text { (mg d.m./mL) }\end{array}$ & $\begin{array}{c}\text { EC } 50 \text { DPPH } \\
\text { (mg d.m./mL) }\end{array}$ & $\begin{array}{c}\text { Total Carotenoid } \\
\text { Content } \\
(\mu \mathrm{g} / \mathrm{g} \text { d.m. })\end{array}$ & $\begin{array}{c}\text { Total Phenolic } \\
\text { Content } \\
\text { (mg GAE/g d.m.) }\end{array}$ \\
\hline \multirow{11}{*}{ 离 } & FRESH & $0.06 \pm 0.01^{\mathrm{f}}$ & $0.21 \pm 0.02^{\mathrm{e}}$ & $104.60 \pm 6.8^{a}$ & $40.25 \pm 8.98^{a}$ \\
\hline & $\mathrm{CD} 50{ }^{\circ} \mathrm{C}$ & $0.17 \pm 0.00 \mathrm{de}$ & $0.48 \pm 0.09 \mathrm{~cd}$ & $40.55 \pm 0.42$ de & $20.79 \pm 2.31^{b}$ \\
\hline & $\mathrm{CD} 60{ }^{\circ} \mathrm{C}$ & $0.36 \pm 0.02^{a}$ & $0.83 \pm 0.0^{\mathrm{a}}$ & $46.73 \pm 1.48^{\text {cde }}$ & $9.1 \pm 0.81^{b}$ \\
\hline & $\mathrm{CD} 70{ }^{\circ} \mathrm{C}$ & $0.26 \pm 0.02^{b c}$ & $0.71 \pm 0.00^{a b}$ & $57.40 \pm 1.58^{b c}$ & $12.57 \pm 0.93^{b}$ \\
\hline & $\mathrm{CD} 80-50{ }^{\circ} \mathrm{C}$ & $0.32 \pm 0.0^{\mathrm{ab}}$ & $0.79 \pm 0.05^{a}$ & $36.55 \pm 2.40^{\mathrm{e}}$ & $10.33 \pm 0.04^{b}$ \\
\hline & $\mathrm{CD} 80-60^{\circ} \mathrm{C}$ & $0.20 \pm 0.01^{\mathrm{cd}}$ & $0.56 \pm 0.07 \mathrm{bc}$ & $62.38 \pm 2.54^{b}$ & $16.32 \pm 0.34^{b}$ \\
\hline & $\operatorname{VD} 50{ }^{\circ} \mathrm{C}$ & $0.05 \pm 0.00^{f}$ & $0.16 \pm 0.00^{\mathrm{e}}$ & $39.55 \pm 0.21^{\mathrm{e}}$ & $44.89 \pm 10.66^{a}$ \\
\hline & $\operatorname{VD} 60^{\circ} \mathrm{C}$ & $0.09 \pm 0.0^{\text {ef }}$ & $0.31 \pm 0.03 \mathrm{de}$ & $90.27 \pm 1.50^{a}$ & $22.68 \pm 2.66^{b}$ \\
\hline & VD $70{ }^{\circ} \mathrm{C}$ & $0.19 \pm 0.04^{\mathrm{cd}}$ & $0.51 \pm 0.00^{\mathrm{bcd}}$ & $63.48 \pm 3.24^{b}$ & $16.86 \pm 2.41^{b}$ \\
\hline & VD $80-50{ }^{\circ} \mathrm{C}$ & $0.22 \pm 0.00 \mathrm{~cd}$ & $0.49 \pm 0.00^{b c d}$ & $55.86 \pm 1.44^{\mathrm{bcd}}$ & $19.3 \pm 0.68^{b}$ \\
\hline & VD $80-60^{\circ} \mathrm{C}$ & $0.24 \pm 0.02 \mathrm{~cd}$ & $0.45 \pm 0.03^{c d}$ & $64.10 \pm 2.05^{b}$ & $14.29 \pm 1.07^{b}$ \\
\hline \multirow{11}{*}{$\frac{\vec{a}}{3}$} & FRESH & $0.05 \pm 0.00^{\mathrm{F}}$ & $0.15 \pm 0.00^{\mathrm{F}}$ & $60.90 \pm 0.85^{\mathrm{AB}}$ & $20.40 \pm 0.28^{\mathrm{A}}$ \\
\hline & $\mathrm{CD} 50^{\circ} \mathrm{C}$ & $0.50 \pm 0.02^{\mathrm{CD}}$ & $3.08 \pm 0.22^{\mathrm{A}}$ & $35.08 \pm 1.19^{\mathrm{B}}$ & $4.77 \pm 0.96^{\mathrm{H}}$ \\
\hline & $\mathrm{CD} 60^{\circ} \mathrm{C}$ & $0.68 \pm 0.00^{B C}$ & $2.45 \pm 0.08^{B C}$ & $44.45 \pm 2.21 \mathrm{DE}$ & $4.83 \pm 1.05^{\mathrm{GH}}$ \\
\hline & $\mathrm{CD} 70^{\circ} \mathrm{C}$ & $0.76 \pm 0.00 \mathrm{AB}$ & $2.61 \pm 0.08 \mathrm{AB}$ & $53.25 \pm 0.80^{\mathrm{BC}}$ & $7.5 \pm 0.67 \mathrm{EFG}$ \\
\hline & $\mathrm{CD} 80-50^{\circ} \mathrm{C}$ & $0.83 \pm 0.08^{\mathrm{AB}}$ & $2.03 \pm 0.08^{C D}$ & $38.91 \pm 1.13^{\mathrm{EF}}$ & $7.25 \pm 0.40^{\mathrm{FGH}}$ \\
\hline & $\mathrm{CD} 80-60^{\circ} \mathrm{C}$ & $0.91 \pm 0.01^{\mathrm{A}}$ & $1.90 \pm 0.12^{\mathrm{E}}$ & $42.49 \pm 1.23^{\mathrm{EF}}$ & $10.48 \pm 0.11^{\mathrm{D}}$ \\
\hline & $\operatorname{VD} 50^{\circ} \mathrm{C}$ & $0.25 \pm 0.01^{\mathrm{E}}$ & $0.94 \pm 0.21^{\mathrm{E}}$ & $61.49 \pm 2.41^{\mathrm{A}}$ & $14.57 \pm 1.36^{C}$ \\
\hline & VD $60{ }^{\circ} \mathrm{C}$ & $0.29 \pm 0.04^{\mathrm{E}}$ & $0.99 \pm 0.18^{\mathrm{E}}$ & $51.57 \pm 1.64^{C D}$ & $17.51 \pm 0.66^{\mathrm{B}}$ \\
\hline & $\operatorname{VD} 70^{\circ} \mathrm{C}$ & $0.39 \pm 0.04^{\mathrm{DE}}$ & $1.20 \pm 0.04^{\mathrm{E}}$ & $44.86 \pm 0.31 \mathrm{DE}$ & $10.61 \pm 0.15^{\mathrm{D}}$ \\
\hline & VD $80-50{ }^{\circ} \mathrm{C}$ & $0.35 \pm 0.04^{\mathrm{DE}}$ & $1.05 \pm 0.11^{\mathrm{E}}$ & $61.88 \pm 1.05^{\mathrm{A}}$ & $10.22 \pm 0.07^{\mathrm{DE}}$ \\
\hline & VD $80-60^{\circ} \mathrm{C}$ & $0.54 \pm 0.05^{C D}$ & $1.23 \pm 0.03^{\mathrm{E}}$ & $56.19 \pm 1.23^{\mathrm{ABC}}$ & $9.48 \pm 0.04 \mathrm{DEF}$ \\
\hline
\end{tabular}

$\mathrm{CD}$, convective drying; VD, vacuum drying; and EC 50, half maximal effective concentration. The number adjacent to the drying method abbreviation signifies the applied temperature. Means in either columns sharing the same superscript letters (small and capital letters for Genewa and Weiki cultivar, respectively) are not significantly different from each other (Tukey's HSD, $p<0.05$ ).

\subsection{Drying Kinetics}

Drying curves of the kiwi samples are presented in Figure 1a-d. The fastest drying was achieved when the temperature was set at $70{ }^{\circ} \mathrm{C}$. The time needed to reach $\mathrm{MR}=0.02 \mathrm{in}$ such conditions for the Weiki cultivar ranged from 636 to $668 \mathrm{~min}$ for the VD (Figure 1d) and CD (Figure 1c) drying methods, respectively. For the Geneva cultivar, the desired MR of dried samples was obtained after $642 \mathrm{~min}$ for VD (Figure 1b) and $802 \mathrm{~min}$ for CD (Figure 1a). In comparison, the longest drying time was observed at the lowest temperature $\left(50^{\circ} \mathrm{C}\right)$ for $\mathrm{CD}$ and it varied between 1528 and $1756 \mathrm{~min}$ for Weiki (Figure 1c) and Geneva (Figure 1d), respectively. Two-stage drying $\left(80-50\right.$ and $\left.80-60^{\circ} \mathrm{C}\right)$ turned out to be an ineffective method of speeding up the process. Measured time differences between one- and two-stage processes were insignificant. 


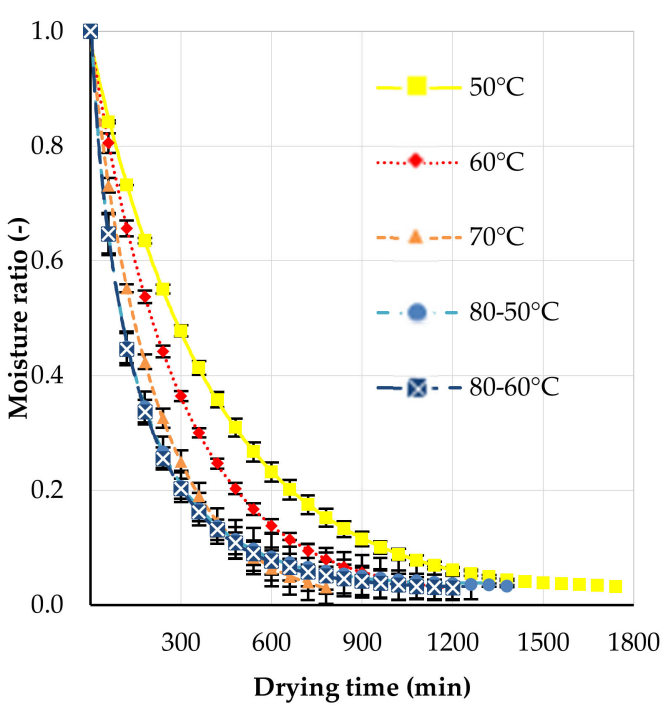

(a)

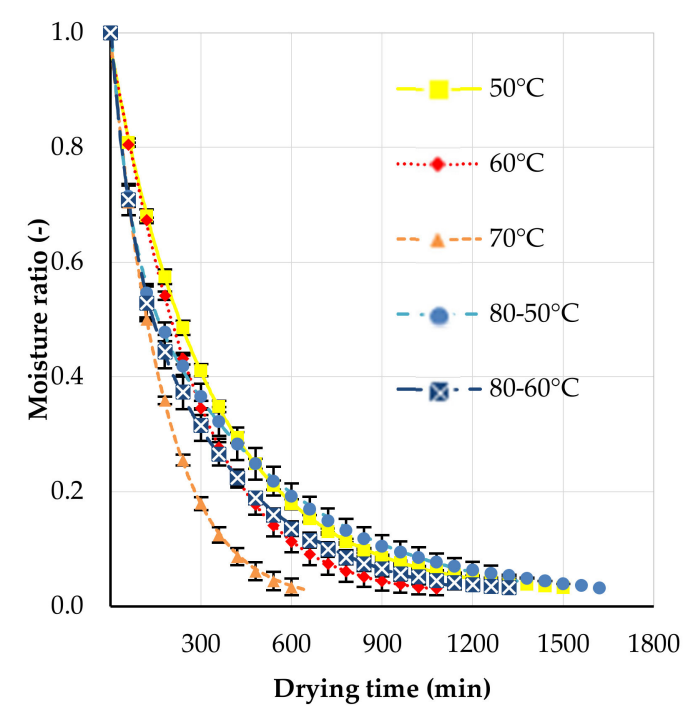

(c)

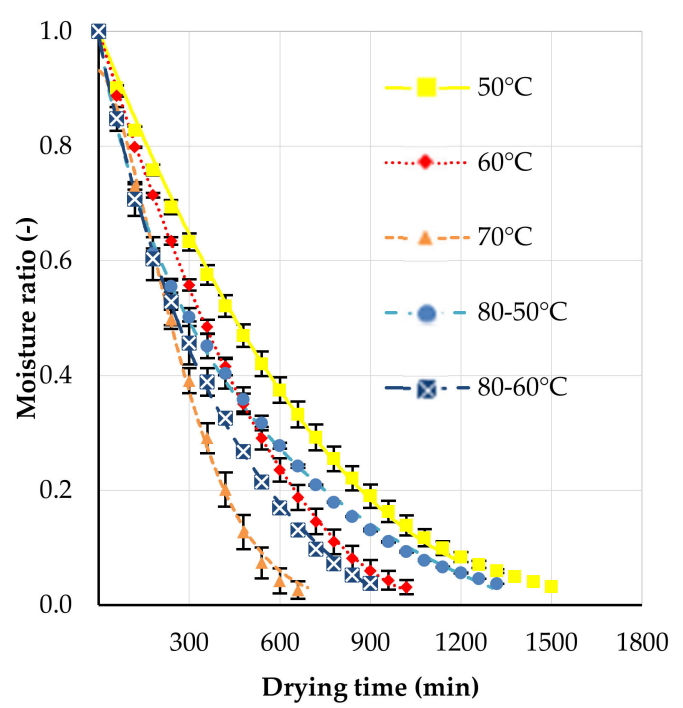

(b)

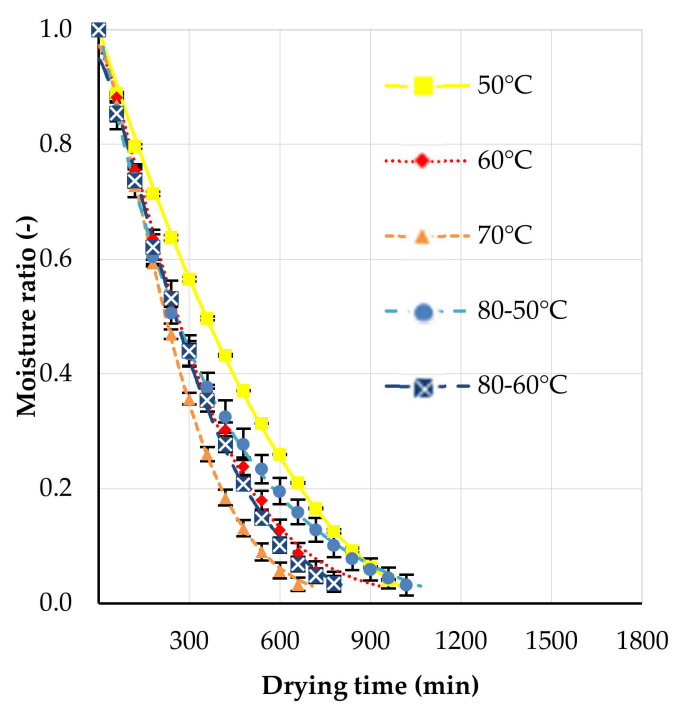

(d)

Figure 1. Moisture ratio (MR) kinetics of dried (a) Geneva using the convective method, (b) Geneva using the vacuum method, (c) Weiki using the convective method, and (d) Weiki using the vacuum method.

\subsection{Mathematical Modeling}

Mathematical modeling is one of the tools used for describing the drying process of fruits and vegetables $[28,29]$. Different models exhibit potential both in predicting and explaining factors influencing drying. Statistical analysis (Table 3) showed that all applied models can be used for predicting changes in moisture ratio during drying. Generally, the best-fitting model was proposed by Midilli et al. [20]. Values of the coefficient of determination $\left(R^{2}\right)$ were between 0.999 and 0.997 , root mean square error (RMSE) was between 0.0018 and 0.0170 , and reduced mean chi-squared statistic $\left(\chi^{2}\right)$ was between $1.82 \times 10^{-6}$ and $1.37 \times 10^{-4}$.

In the current study, the highest values of the effective water diffusion coefficient $\left(\mathrm{D}_{\text {eff }}\right)$ were stated for $\mathrm{CD}$ dried Weiki at $70^{\circ} \mathrm{C}$ and was equal to $9.589 \times 10^{-10} \mathrm{~m}^{2} / \mathrm{s}$ (Table 4 ). In turn, the lowest $D_{\text {eff }}$ values were obtained for the fruits dried at $50^{\circ} \mathrm{C}$ and they were equal to $3.093 \times 10^{-10}$ and $3.113 \times 10^{-10} \mathrm{~m}^{2} / \mathrm{s}$ for VD Geneva and CD Weiki, respectively. The differences between $D_{\text {eff }}$ values obtained using different drying methods were also observed by other authors. 
Table 3. Statistical analysis of evaluated best fitted mathematical models for tested methods of drying.

\begin{tabular}{|c|c|c|c|c|c|}
\hline Cultivar & $\begin{array}{l}\text { Drying Method } \\
\text { and Temperature }\end{array}$ & $\begin{array}{l}\text { Model Name and } \\
\text { Reference }\end{array}$ & RMSE & $x^{2}$ & $\mathbf{R}^{2}$ \\
\hline \multirow{10}{*}{ Geneva } & $\mathrm{CD} 50^{\circ} \mathrm{C}$ & Logarithmic [18] & 0.0025 & $4.91 \times 10^{-6}$ & 0.999 \\
\hline & $\mathrm{CD} 60^{\circ} \mathrm{C}$ & Midilli et al. [20] & 0.0019 & $1.82 \times 10^{-6}$ & 0.999 \\
\hline & $\mathrm{CD} 70^{\circ} \mathrm{C}$ & Two-factor [23] & 0.0018 & $6.51 \times 10^{-6}$ & 0.999 \\
\hline & $\mathrm{CD} 80-50{ }^{\circ} \mathrm{C}$ & Midilli et al. [20] & 0.0071 & $2.64 \times 10^{-5}$ & 0.999 \\
\hline & $\mathrm{CD} 80-60^{\circ} \mathrm{C}$ & Midilli et al. [20] & 0.0067 & $2.45 \times 10^{-5}$ & 0.999 \\
\hline & $\operatorname{VD} 50^{\circ} \mathrm{C}$ & Wang [21] & 0.0110 & $9.44 \times 10^{-5}$ & 0.998 \\
\hline & $\operatorname{VD} 60^{\circ} \mathrm{C}$ & Wang [21] & 0.0055 & $1.51 \times 10^{-5}$ & 0.999 \\
\hline & $\operatorname{VD} 70^{\circ} \mathrm{C}$ & Midilli et al. [20] & 0.0170 & $1.37 \times 10^{-4}$ & 0.997 \\
\hline & VD $80-50{ }^{\circ} \mathrm{C}$ & Midilli et al. [20] & 0.0118 & $7.29 \times 10^{-5}$ & 0.998 \\
\hline & VD $80-60{ }^{\circ} \mathrm{C}$ & Midilli et al. [20] & 0.0118 & $7.29 \times 10^{-5}$ & 0.998 \\
\hline \multirow{10}{*}{ Weiki } & $\mathrm{CD} 50{ }^{\circ} \mathrm{C}$ & Midilli et al. [20] & 0.0033 & $5.33 \times 10^{-5}$ & 0.999 \\
\hline & $\mathrm{CD} 60^{\circ} \mathrm{C}$ & Midilli et al. [20] & 0.0048 & $1.21 \times 10^{-5}$ & 0.999 \\
\hline & $\mathrm{CD} 70{ }^{\circ} \mathrm{C}$ & Midilli et al. [20] & 0.0030 & $6.51 \times 10^{-6}$ & 0.999 \\
\hline & $\mathrm{CD} 80-50{ }^{\circ} \mathrm{C}$ & Two-factor [23] & 0.0066 & $1.85 \times 10^{-5}$ & 0.999 \\
\hline & $\mathrm{CD} 80-60{ }^{\circ} \mathrm{C}$ & Two-factor [23] & 0.0056 & $1.26 \times 10^{-5}$ & 0.999 \\
\hline & $\operatorname{VD} 50^{\circ} \mathrm{C}$ & Wang [21] & 0.0078 & $2.93 \times 10^{-5}$ & 0.999 \\
\hline & $\operatorname{VD} 60^{\circ} \mathrm{C}$ & Midilli et al. [20] & 0.0138 & $6.51 \times 10^{-6}$ & 0.997 \\
\hline & $\operatorname{VD} 70^{\circ} \mathrm{C}$ & Midilli et al. [20] & 0.0061 & $2.66 \times 10^{-5}$ & 0.999 \\
\hline & VD $80-50{ }^{\circ} \mathrm{C}$ & Midilli et al. [20] & 0.0104 & $4.52 \times 10^{-5}$ & 0.998 \\
\hline & VD $80-60^{\circ} \mathrm{C}$ & Midilli et al. [20] & 0.0128 & $6.58 \times 10^{-5}$ & 0.998 \\
\hline
\end{tabular}

$\mathrm{CD}$, convective drying and $\mathrm{VD}$, vacuum drying. The number adjacent to the drying method abbreviation signifies the applied temperature.

Table 4. Effective water diffusion coefficient computed from simplified Fick's second law of diffusion.

\begin{tabular}{|c|c|c|}
\hline \multirow{2}{*}{ Drying Method and Temperature } & \multicolumn{2}{|c|}{$D_{\text {eff }}\left(10^{-10} \mathrm{~m}^{2} / \mathrm{s}\right)$} \\
\hline & Geneva & Weiki \\
\hline $\mathrm{CD} 50^{\circ} \mathrm{C}$ & $4.016 \pm 0.003^{c}$ & $3.113 \pm 0.003^{a}$ \\
\hline $\mathrm{CD} 60^{\circ} \mathrm{C}$ & $5.498 \pm 0.007^{\mathrm{h}}$ & $5.958 \pm 0.012^{j}$ \\
\hline $\mathrm{CD} 70{ }^{\circ} \mathrm{C}$ & $7.702 \pm 0.011 \mathrm{~m}$ & $9.589 \pm 0.024^{\circ}$ \\
\hline $\mathrm{CD} 80-50^{\circ} \mathrm{C}$ & $7.740 \pm 0.082 \mathrm{~m}$ & $4.514 \pm 0.009^{\mathrm{e}}$ \\
\hline $\mathrm{CD} 80-60^{\circ} \mathrm{C}$ & $8.055 \pm 0.076^{n}$ & $5.435 \pm 0.037^{\mathrm{h}}$ \\
\hline $\operatorname{VD} 50^{\circ} \mathrm{C}$ & $3.093 \pm 0.014^{\mathrm{a}}$ & $4.013 \pm 0.028^{c}$ \\
\hline VD $60^{\circ} \mathrm{C}$ & $4.315 \pm 0.033^{d}$ & $5.532 \pm 0.033^{h}$ \\
\hline VD $70{ }^{\circ} \mathrm{C}$ & $6.665 \pm 0.065^{k}$ & $6.900 \pm 0.047^{1}$ \\
\hline VD $80-50{ }^{\circ} \mathrm{C}$ & $3.656 \pm 0.013^{b}$ & $4.847 \pm 0.015^{f}$ \\
\hline VD $80-60{ }^{\circ} \mathrm{C}$ & $4.980 \pm 0.029 \mathrm{~g}$ & $5.709 \pm 0.047^{\mathrm{i}}$ \\
\hline
\end{tabular}

$\mathrm{CD}$, convective drying and $\mathrm{VD}$, vacuum drying. The number adjacent to the drying method abbreviation signifies the applied temperature. Means within columns sharing the same superscript are not significantly different from each other $(p<0.05)$. 


\section{Discussion}

\subsection{Biochemical Properties}

Both of these cultivars, in fresh form, were also examined by Wojdyło et al. [30]. Presented DPPH values of fresh fruits were equal to 13.08 and $10.36 \mathrm{mmol}$ TEAC/g d.m. for Geneva and Weiki cultivars, respectively.

Dried Weiki fruits presented lower bioactivity than Geneva (Table 2). As it was previously mentioned, fresh Geneva fruits have higher antioxidant activity (as evaluated by the DPPH method) than Weiki fruits [31]. Moreover, the chemical compounds developed during the drying process can also show antioxidant activity. Even though total phenolic content can decrease, the overall antioxidant potential can be preserved. This phenomenon was observed and described by Wojdyło et al. [32] for convective, vacuum, and vacuum-microwave drying of strawberries. They explained the rise in measured antioxidant power in convective dried sample creation of Maillard reaction products, which have antioxidant properties. When obtained $\mathrm{EC}_{50}$ (ABTS) and $\mathrm{EC}_{50}(\mathrm{DPPH})$ values are considered, convective drying yields better conditions for processing in the case of both cultivars. This is a rather surprising result because of the presence of oxygen, which is a substrate for enzymatic and nonenzymatic oxidation.

Beta and Hwang [33] monitored the influence of heating time and moisture content on total carotenoids contents in orange maize flour. They observed the degradation of carotenoids with longer processing and higher moisture content. After $180 \mathrm{~min}$ of the heating at $100{ }^{\circ} \mathrm{C}$, total carotenoid contents dropped from the initial $41.48 \mu \mathrm{g} / \mathrm{g}$ to 31.29 and $14.81 \mu \mathrm{g} / \mathrm{g}$ at $0 \%$ and $70 \% v / w$ moisture content, respectively.

Phenolic composition of fresh kiwiberry was also investigated by Wojdyło et al. [30]. TPC values obtained in this research ranged between 38.13 and $36.91 \mathrm{mg} \mathrm{GAE} / \mathrm{g} \mathrm{d.m}$. for Geneva and Weiki, respectively. This suggests that low-temperature CD and VD drying in the case of the Geneva cultivar allows comparable TPC values to the fresh fruits.

The results from this experiment suggest that, among tested methods, VD is better for the preservation of the phenolic and carotenoids compounds. Such behavior is related to the lack of oxygen, which is essential for oxidation reactions. Moreover, it could be related to the activity of enzymes (polyphenol oxidase (PPO) and peroxidase (PO)) which can lead to oxidation of phenolics and carotenoids during drying. It was reported that PPO can remain active for $120 \mathrm{~min}$ at a temperature of 40 and $50{ }^{\circ} \mathrm{C}$ [34]. Another possible explanation is related to the chemical structures of the studied compounds; for instance, carotenoids contain a lot of double bonds, which are sensitive to oxidation that occurs when the process proceeds at elevated temperatures and/or with the presence of air in the environment. The performed statistical analysis demonstrated also that all factors, namely cultivar, drying method, and drying temperature, had significant impacts $(p<0.05)$ on all investigated chemical properties. However, in the case of the $\mathrm{EC}_{50}$ measured by both ABTS and DPPH and TPC, the highest impact on variability of the results was stated for the cultivar $\left(\eta^{2}=0.964, \eta^{2}=0.0 .985\right.$, and $\eta^{2}=852$, for $\mathrm{EC}_{50} \mathrm{ABTS}, \mathrm{EC}_{50} \mathrm{DPPH}$, and TPC, respectively). On the contrary, for TCC, drying method played the most important role in value shaping $\left(\eta^{2}=0.938\right)$. Such results indicate that cultivar selection is of paramount importance for final properties of dried kiwiberry.

\subsection{Drying Kinetics}

The obtained results are in accordance with the previously reported dependency between drying time and temperature, i.e., the increment of the temperature reduces drying time. Such results have been reported for kiwifruits (Actinidia deliciosa) using both air and vacuum drying methods [5,35], for apples [36], for bananas [37], for blueberries [38], and for maqui fruits [39]. In the current study, two-stage drying, despite higher values of the diffusion coefficient, did not lead to shorter drying time. Similar results were reported for onion: the drying times were very similar when the temperature 
during processing was shifted from 85 to $75{ }^{\circ} \mathrm{C}$ and when the whole process was carried out at $75^{\circ} \mathrm{C}[40]$.

\subsection{Mathematical Modeling}

In the experiment performed by Bialik et al. [6], the researchers performed an analysis of kiwiberry drying using convective, microwave, and vacuum methods. They established that, for drying at $70{ }^{\circ} \mathrm{C}$, Midilli's model offered the best fit for CD and VD methods. In the cited research, $R^{2}$ varied between 0.999 and 0.997 , RMSE varied between 0.0041 and 0.0147 , and $\chi^{2}$ varied between $1.756 \times 10^{-5}$ and $1.82 \times 10^{-6}$. Statistical analysis of kinetics for drying Kiwi showed the best model fit from simplified Fick's second law of diffusion. The results obtained in the current research are similar. The coefficient of determination in the current experiment $\left(R^{2}\right)$ was in the range between 0.998 to 0.999 , RMSE deviated between 0.0052 and 0.0255 , and $\chi^{2}$ values ranged from $9.275 \times 10^{-5}$ to $6.72 \times 10^{-4}$.

Maritza et al. [41] studied the influence of instant control pressure drop on different aspects of drying strawberries using convective, freeze, and swell drying methods. The highest value was established for swell drying with $D_{\text {eff }}$ at $5.00 \times 10^{-10} \mathrm{~m}^{2} / \mathrm{s}$ against $0.11 \times 10^{-10} \mathrm{~m}^{2} / \mathrm{s}$ for control samples obtained using the convective method. Arslan and Özcan [42] reported the effective diffusivity values of pepper slices comparing the sun, convective, and microwave drying processes. Depending on the parameters of the process, they established values ranging from $0.31 \times 10^{-9} \mathrm{~m}^{2} / \mathrm{s}$ to $87.39 \times 10^{-9} \mathrm{~m}^{2} / \mathrm{s}$ for sun and microwave methods, respectively. Obtained $D_{\text {eff }}$ values were compared by means of Pearson's correlation with determined chemical properties. Significant correlation was found between $\mathrm{D}_{\text {eff }}$ and TPC $(\mathrm{r}=-0.635 ; p<0.05)$ and $\mathrm{D}_{\text {eff }}$ and TCC $(\mathrm{r}=0.697 ; p<0.05)$ for VD and CD, respectively. In the case of $C D$, positive value of Pearson's correlation coefficient indicated that faster removal of water, which is linked to faster drying rate, could be related to better retention of carotenoids. No such correlation has been found for VD and TCC. Such results confirm the aforementioned explanation about the sensitivity of carotenoids for extended processing in the presence of air. However, a negative correlation between TPC and $D_{\text {eff }}$ demonstrates that degradation of phenolics occurs faster when water is removed faster from kiwiberry and that it is not linked to the presence of air (no significant correlation found for $\mathrm{CD}$ ).

\section{Conclusions}

The conducted research showed that higher drying temperatures of kiwiberry accelerated the kinetics of drying but also negatively affected the antioxidant activity of dried fruit extracts or total phenolic content. The total carotenoid content was, in most cases, higher when the temperature used during vacuum and convective drying was higher, which was related to a shorter processing time and hence shorter exposition to air and/or elevated temperature. Dried samples obtained from the Geneva variety of kiwiberry were characterized by higher total phenolic concentration, total carotenoid content, and antioxidant activity (as determined by $\mathrm{ABTS}^{\bullet+}$ and $\mathrm{DPPH}^{\bullet}$ assays) when compared to the Weiki cultivar. The results from this experiment suggest that the vacuum drying method has a potential to obtain materials with higher concentrations of bioactive compounds and greater free radical scavenging activity than $\mathrm{CD}$, especially when performed at $60^{\circ} \mathrm{C}$. This mathematical modeling of drying has proven its usefulness for the prediction of drying kinetics.

Author Contributions: Conceptualization, M.B., E.G., and D.W.-R.; methodology, M.B., K.R., and A.W.; formal analysis, M.B., E.G., and A.W.; investigation, M.B., K.R., and A.W.; resources, P.L.; data curation, M.B.; writing-original draft preparation, M.B. and A.W.; writing—review and editing, M.B., A.W., E.G., and D.W.-R.; visualization, M.B.; supervision, E.G. and A.W. All authors have read and agreed to the published version of the manuscript.

Funding: This research received no external funding.

Conflicts of Interest: The authors declare no conflict of interest. 


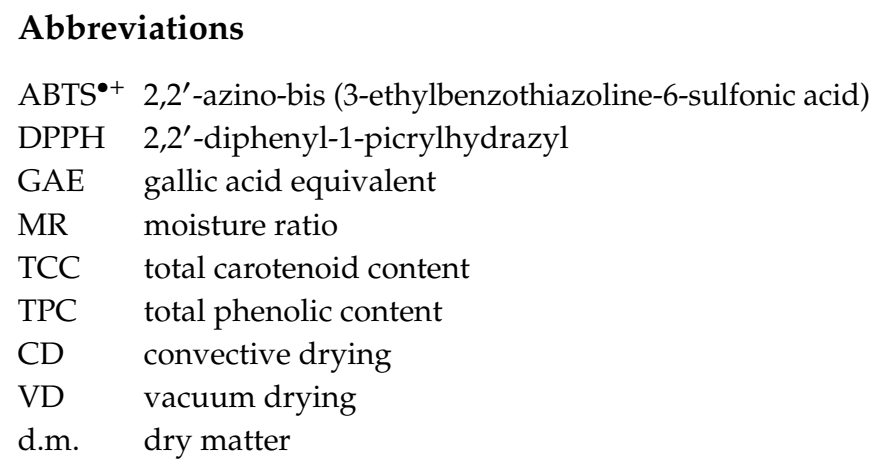

\section{References}

1. Latocha, P.; Łata, B.; Stasiak, A. Phenolics, ascorbate and the antioxidant potential of kiwiberry vs. common kiwifruit: The effect of cultivar and tissue type. J. Funct. Foods 2015, 19, 155-163. [CrossRef]

2. Latocha, P. The nutritional and health benefits of kiwiberry (Actinidia arguta)—A review. Plant Foods Hum. Nutr. 2017, 72, 325-334. [CrossRef] [PubMed]

3. Gorinstein, S.; Leontowicz, H.; Leontowicz, M.; Jesion, I.; Namiesnik, J.; Drzewiecki, J.; Park, Y.-S.; Ham, K.-S.; Giordani, E.; Trakhtenberg, S. Influence of two cultivars of persimmon on atherosclerosis indices in rats fed cholesterol-containing diets: Investigation in vitro and in vivo. Nutrition 2011, 27, 838-846. [CrossRef] [PubMed]

4. Kowalski, S.J.; Mierzwa, D. Influence of Osmotic Pretreatment on Kinetics of Convective Drying and Quality of Apples. Dry. Technol. 2013, 31, 1849-1855. [CrossRef]

5. Orikasa, T.; Koide, S.; Okamoto, S.; Imaizumi, T.; Muramatsu, Y.; Takeda, J.; Shiina, T.; Tagawa, A. Impacts of hot air and vacuum drying on the quality attributes of kiwifruit slices. J. Food Eng. 2014, 125, 51-58. [CrossRef]

6. Bialik, M.; Gondek, E.; Wiktor, A.; Latocha, P.; Witrowa-Rajchert, D. Mathematical Modeling of Actinidia arguta (Kiwiberry) Drying Kinetics. Agric. Eng. 2017, 21, 5-13. [CrossRef]

7. Li, H.; Zeng, C.; Wei, J.; Yang, T.; Gao, S.; Li, Y.; Lei, G. Associations between dietary antioxidants intake and radiographic knee osteoarthritis. Clin. Rheumatol. 2016, 35, 1585-1592. [CrossRef]

8. Pattison, D.; White, A. Diet and complementary therapies. In Rheumatology; Elsevier: Amsterdam, The Netherlands, 2010; pp. 185-197.

9. Del Giudice, R.; Petruk, G.; Raiola, A.; Barone, A.; Monti, D.M.; Rigano, M.M. Carotenoids in fresh and processed tomato (Solanum lycopersicum) fruits protect cells from oxidative stress injury: Tomato carotenoids protect cells from oxidative stress injury. J. Sci. Food Agric. 2017, 97, 1616-1623. [CrossRef]

10. Zotarelli, M.F.; Porciuncula, B.D.A.; Laurindo, J.B. A convective multi-flash drying process for producing dehydrated crispy fruits. J. Food Eng. 2012, 108, 523-531. [CrossRef]

11. Piotrowski, D.; Lenart, A. Operating parameters of computerised stand for drying fruits under lowered pressure. Inży. Roln. 2002, 6, 283-290. (In Polish)

12. AOAC International. Official Methods of Analysis of AOAC International, 20th ed.; Latimer, G.W., AOAC International, Eds.; AOAC International: Gaithersburg, MD, USA, 2016; ISBN 978-0-935584-87-5.

13. Brand-Williams, W.; Cuvelier, M.E.; Berset, C. Use of a free radical method to evaluate antioxidant activity. LWT Food Sci. Technol. 1995, 28, 25-30. [CrossRef]

14. Polish Committee for Standardization. Polish Standard PN-EN12136:2000. Fruit and Vegetable Juices-Determination of Total Carotenoid Content and Individual Carotenoid Fractions; Polish Committee for Standardization: Warsaw, Poland, 2000.

15. Lichtenthaler, H.K.; Wellburn, A.R. Determinations of total carotenoids and chlorophylls $a$ and $b$ of leaf extracts in different solvents. Biochem. Soc. Trans. 1983, 11, 591-592. [CrossRef]

16. Singleton, V.L.; Rossi, J.A. Colorimetry of Total Phenolics with Phosphomolybdic-Phosphotungstic Acid Reagents. Am. J. Enol. Vitic. 1965, 16, 144.

17. Demir, V.; Gunhan, T.; Yagcioglu, A.K.; Degirmencioglu, A. Mathematical Modelling and the Determination of Some Quality Parameters of Air-dried Bay Leaves. Biosyst. Eng. 2004, 88, 325-335. [CrossRef] 
18. Sarimeseli, A. Microwave drying characteristics of coriander (Coriandrum sativum L.) leaves. Energy Convers. Manag. 2011, 52, 1449-1453. [CrossRef]

19. Rahman, M.S.; Perera, C.O.; Thebaud, C. Desorption isotherm and heat pump drying kinetics of peas. Food Res. Int. 1997, 30, 485-491. [CrossRef]

20. Midilli, A.; Kucuk, H.; Yapar, Z. A new model for single-layer drying. Dry. Technol. 2002, 20, 1503-1513. [CrossRef]

21. Wang, C.Y.; Singh, R.P. Use of variable equilibrium moisture content in modeling rice drying. Trans. Am. Soc. Agric. Eng. 1978, 11, 668-672.

22. Soysal, Y.; Öztekin, S.; Eren, Ö. Microwave drying of parsley: Modelling, kinetics, and energy aspects. Biosyst. Eng. 2006, 93, 403-413. [CrossRef]

23. Arslan, D.; Özcan, M.M.; Mengeş, H.O. Evaluation of drying methods with respect to drying parameters, some nutritional and colour characteristics of peppermint (Mentha x piperita L.). Energy Convers. Manag. 2010, 51, 2769-2775. [CrossRef]

24. Ramaswamy, H.S.; Nsonzi, F. Convective-air drying kinetics of osmotically pre-treated blueberries. Dry. Technol. 1998, 16, 743-759. [CrossRef]

25. Wiktor, A.; Nowacka, M.; Dadan, M.; Rybak, K.; Lojkowski, W.; Chudoba, T.; Witrowa-Rajchert, D. The effect of pulsed electric field on drying kinetics, color, and microstructure of carrot. Dry. Technol. 2016, 34, 1286-1296. [CrossRef]

26. Ah-Hen, K.; Zambra, C.E.; Aguëro, J.E.; Vega-Gálvez, A.; Lemus-Mondaca, R. Moisture Diffusivity Coefficient and Convective Drying Modelling of Murta (Ugni molinae Turcz): Influence of Temperature and Vacuum on Drying Kinetics. Food Bioprocess Technol. 2013, 6, 919-930. [CrossRef]

27. Crank, J. The Mathematics of Diffusion, 2nd ed.; Oxford University Press: Oxford, UK, 1975; ISBN 978-0-19-853411-2.

28. Wiktor, A.; Iwaniuk, M.; Śledź, M.; Nowacka, M.; Chudoba, T.; Witrowa-Rajchert, D. Drying Kinetics of Apple Tissue Treated by Pulsed Electric Field. Dry. Technol. 2013, 31, 112-119. [CrossRef]

29. Haq, R.; Kumar, P.; Prasad, K. Effect of microwave treatment on dehydration kinetics and moisture diffusivity of Asiatic Himalayan black carrot. J. Saudi Soc. Agric. Sci. 2016, 17, 463-470. [CrossRef]

30. Wojdyło, A.; Nowicka, P.; Oszmiański, J.; Golis, T. Phytochemical compounds and biological effects of Actinidia fruits. J. Funct. Foods 2017, 30, 194-202. [CrossRef]

31. Latocha, P.; Krupa, T.; Wołosiak, R.; Worobiej, E.; Wilczak, J. Antioxidant activity and chemical difference in fruit of different Actinidia sp. Int. J. Food Sci. Nutr. 2010, 61, 381-394. [CrossRef]

32. Wojdyło, A.; Figiel, A.; Oszmiański, J. Effect of Drying Methods with the Application of Vacuum Microwaves on the Bioactive Compounds, Color, and Antioxidant Activity of Strawberry Fruits. J. Agric. Food Chem. 2009, 57, 1337-1343. [CrossRef]

33. Beta, T.; Hwang, T. Influence of heat and moisture treatment on carotenoids, phenolic content, and antioxidant capacity of orange maize flour. Food Chem. 2018, 246, 58-64. [CrossRef]

34. Mizobutsi, G.P.; Finger, F.L.; Ribeiro, R.A.; Puschmann, R.; Neves, L.L.d.M.; da Mota, W.F. Effect of pH and temperature on peroxidase and polyphenoloxidase activities of litchi pericarp. Sci. Agric. 2010, 67, $213-217$. [CrossRef]

35. Chin, C.K.; Siew, E.S.; Soon, W.L. Drying Characteristics and Quality Evaluation of Kiwi Slices Under Hot Air Natural Convective Drying Method. Int. Food Res. J. 2015, 22, 2188-2195.

36. Guiné, R.P.F.; Cruz, A.C.; Mendes, M. Convective Drying of Apples: Kinetic Study, Evaluation of Mass Transfer Properties and Data Analysis using Artificial Neural Networks. Int. J. Food Eng. 2014, 10, 281-299. [CrossRef]

37. Khawas, P.; Dash, K.K.; Das, A.J.; Deka, S.C. Drying Characteristics and Assessment of Physicochemical and Microstructural Properties of Dried Culinary Banana Slices. Int. J. Food Eng. 2015, 5. [CrossRef]

38. Yu, Y.; Jin, T.Z.; Xiao, G. Effects of pulsed electric fields pretreatment and drying method on drying characteristics and nutritive quality of blueberries. J. Food Process. Preserv. 2017, 41, e13303. [CrossRef]

39. Rodríguez, K.; Ah-Hen, K.S.; Vega-Gálvez, A.; Vásquez, V.; Quispe-Fuentes, I.; Rojas, P.; Lemus-Mondaca, R. Changes in bioactive components and antioxidant capacity of maqui, Aristotelia chilensis [Mol] Stuntz, berries during drying. LWT Food Sci. Technol. 2016, 65, 537-542. [CrossRef]

40. Ostermeier, R.; Parniakov, O.; Töpfl, S.; Jäger, H. Applicability of Pulsed Electric Field (PEF) Pre-Treatment for a Convective Two-Step Drying Process. Foods 2020, 9, 512. [CrossRef] 
41. Maritza, A.-M.; Sabah, M.; Anaberta, C.-M.; Montejano-Gaitán, J.G.; Allaf, K. Comparative Study of Various Drying Processes at Physical and Chemical Properties of Strawberries (Fragariavarcamarosa). Procedia Eng. 2012, 42, 267-282. [CrossRef]

42. Arslan, D.; Özcan, M.M. Dehydration of red bell-pepper (Capsicum annuum L.): Change in drying behavior, colour and antioxidant content. Food Bioprod. Process. 2011, 89, 504-513. [CrossRef] 